Music Library Association

Mountain Plains Library Association

January 1974

Pennsylvania Library Association,

College and Research

Library Division

Oklahoma Library Association

Wyoming Library Association, Academic and Special

Libraries Section

Wyoming Library Association

Montana Library Association,

Academic and Special

Libraries Division

Medical Library Association

\section{March 1974}

March 1974

April 1974

April 1974

April 1974

May 1974

June 1974
New York Library Association, College and University

Libraries Section

September 1974

St. Croix Library

Association

September 1974

Library Association of the City

University of New York

May 1975

Academic Library Association of Ohio

July 1975

Louisiana Library Association, Academic Section

April 1976

American Historical Association

October 1976

\title{
UCSC Library Starts Move into New Addition
}

The "big move" is on.

Two years ago-in November of 1974ground was broken for a five-story, 43,000square-foot addition to the Dean E. McHenry Library at University of California, Santa Cruz.

In November, with completion of the new $\$ 2.8$ million extension, staff began the job of

\section{Recruitment Open for Editor of ACRL Publications in Librarianship}

ACRL's highly esteemed monographic series, ACRL Publications in Librarianship, will require a new editor in June, when current editor Kenneth G. Peterson will complete a five-year nonrenewable term. A subcommittee of the ACRL Publications Committee is now accepting applications for this volunteer professional post and will make a recommendation to the ACRL president before the Annual Conference.

Besides ACRL membership, persons seeking the appointment should offer a background of service in academic or research librarianship, experience in research, editing, and bibliographical activities, the ability to analyze manuscripts for content, research methods, form, structure, and style, and a concern with publication as a means of professional communication.

Inquiries and expressions of interest, accompanied by a statement of qualifications, should be sent to Nina Cohen, Chairperson, Search Subcommittee for ACRL Publications in Librarianship Editor, Wesleyan University Library, Middletown, CT 06457 by April 1 . rearranging some 350,000 books within the expanded building and shelving another 50,000 books which, until now, had been held in storage.

The major part of the project-erecting several hundred shelving units, putting them in place, and filling them with books-is expected to take "about two months," according to Associate University Librarian Wendell Simons, who is in charge of the move.

"It's good to have some elbow room," says University Librarian David Heron, noting that the library's core collection of 80,000 books has increased to 515,000 volumes in the 11 years since the campus accepted its first students. "With this new addition," he adds, "we now

News items for inclusion in C\&RL News should be sent to John $V$. Crowley. Assistant Director of Libraries, Milne Library, State University College. Oneonta, NY 13820. Advertising (including classilied ads) should be sent to Leona Swiech, Advertising Olfice, American Library Association, 50 E. Huron St., Chicago, IL 606II. Production and circulation matters are handled by ALA Central Production Unit, at the above address.

News edifor: John V. Crowley, Assistant Director of Libraries, Milne Library, State University College, Oneonta NY 13820. Editor: Richard D. Johnson, Milne Library, State University College, Oneonta, New York I3820. President, ACRL: Connie R. Dunlap. Executive Secretary, ACRL: to be announced.

College 2 Research Libraries is published by the Association of College and Research Libraries, a division of the American Library Association, 17 times yearly-6 bimonthly journal issues and II monthly (combining July-August) News issues-at |201-05 Bluff St. Fulton. MO 6525|. Subscription, $\$ 15.00$ a year or to mambers of the division, $\$ 7.50$, included in dues. Second-class postage paid at Fulton, Missouri 65251.

(C) American Library Association 1977. All material in this journal subject to copyright by the American Library Association may be photocopied for the noncommercial purpose of scientific or educational advancement. 
have a capacity for 750,000 volumes which should serve our needs into the 1980 s."

A "Book Move Update," posted on a large bulletin board near the reference desk, keeps library users informed of the books being relocated.

"So far everything seems to be going smoothly," says Simons. "We have had few complaints. As a matter of fact, we have found a couple of books we thought we had lost; apparently they had fallen between shelves and were hidden from sight, a problem not uncommon to libraries."

Addition of the new extension brings total usable space in the McHenry Library to 115,000 square feet.

Reader stations in the library will be increased from 550 to 900 .

The administrative offices of the university librarian have been moved from the main floor of the library to the third floor in the new section.

The offices of the deans of humanities and social sciences will be transferred to the area vacated by the university librarian and his staft.

Career Planning and Placement is now located on the third floor of the library, and space is being remodeled for Summer Session, Administrative Systems, and other miscellaneous offices on the fourth floor.
UCSC's Dean E. McHenry Library, named for the founding chancellor of the campus, was designed by John Carl Warnecke and Associates of San Francisco; building contractor for the extension was Bogard Construction Co. of Santa Cruz.

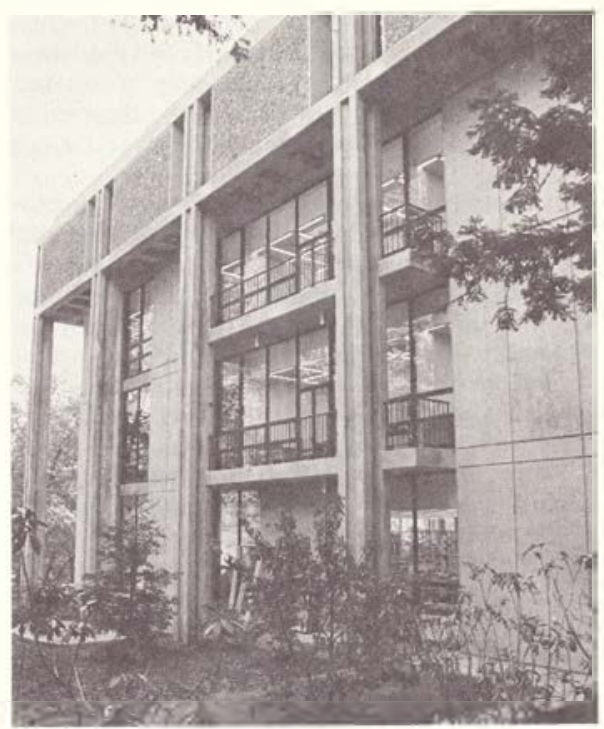

\section{The management best sellep that became a classic.}

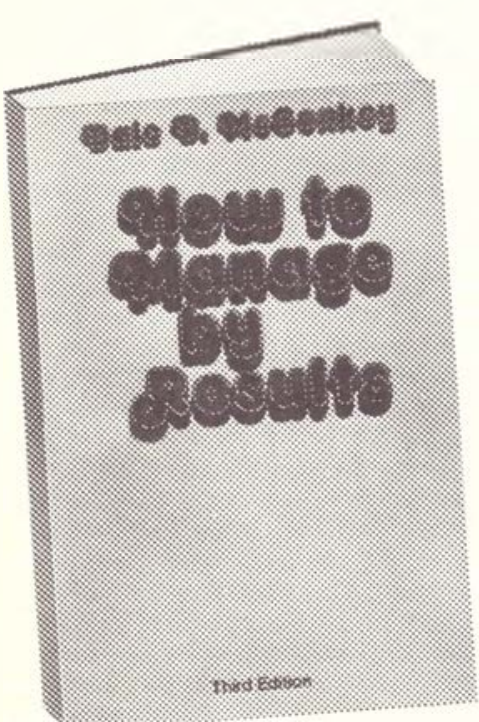

The completely updated 3rd edition of this classic refines the MBO concept . . . Suggests ways of expanding effectiveness... Offers practical solutions to $\mathrm{MBO}$ areas needing constant attention: managerial appraisal vs. actual contribution; actual con. tribution vs. rewards. Plus much more. Published by АМАСОМ, a division of American Management Associations.

\section{HOW TO MANAGE BY RESULTS 3rd Edition by Dale D. McConkey}

